\title{
Sustainability of Indonesian Culture in Global Contemporary Design: Study Case of Buginese Phinisi Ship
}

\author{
F Limano \\ Animation Program, Visual Communication Design Department, School of Design, Bina \\ Nusantara University, Jakarta, Indonesia \\ ferric.limano@binus.ac.id
}

\begin{abstract}
Indonesia reflect the natural diversity and splendor of the routes, moorings, and interiors among thousands of sea-bounded land masses forming this archipelago.Through this research writer will discuss one of the results culture originating in Indonesia, namely Buginese Phinisi ship. Buginese Phinisi ship is sustainability design because the Phinisi ship already exists in 14 century and continue to exist till this day, even a design are continuing developed according the global developments. This Study, Researcher use qualitative descriptive methodology based on picture, literature, and references after that researcher analyze data with STP (Segmentation, Targeting, Positions - Product).
\end{abstract}

Keywords: Phinisi, Ship, Sea-bounded

\section{INTRODUCTION}

Indonesia reflects the natural diversity and splendor of the routes, moorings, and interiors among thousands of sea-bounded land masses forming this archipelago. Although interconnected historically through politics, trade, wars, colonialism, and the formation of the Republic of Indonesia, each island remains distinctive [1]. According to the census 2010 recorded Indonesia has a total 1340 tribe with diverse culture and the result of their culture, unfortunately not the result of culture that is in indonesia known in common by the global community .

One who has popular even though today, still sustain is the Phinisi ship of Buginese. In 1986 the Indonesian government send expedition with a sailboat traditional Phinisi ship from Makassar to Canada in order to participation in Vancouver expo 86 .This expedition Phinisi nusantara told story about heroic and the historic who proved that a traditional sailboat of nusantara capable of being sailed crashing waves across the pacific ocean to the American continent . The first time, its plan to send a sailboat to Canada many met with cynical by various parties. A lot of the media who called cruise Phinisi ship nusantara, it were just project he who drives a coffin. But proved to be then, a Phinisi ship nusantara can realize the plan with honors, does away with all doubt before [2]. Phinisi ship were today is still become a benchmark design a best yacht which is recognized by the global community -- UNESCO 2017 [3]. Focus of this research about result of culture which owned by the Buginese (Indonesia) namely a Phinisi ship. Buginese people, are the main ethnic group of South Sulawesi of Indonesia. Their dominance in number as well as the large area in which they live has made them the most influential ethnic group with regard to economic and political activities in the area. The other ethnic groups of the province are the Makassar, the Mandar and the Toraja. The Bugis are commonly known among their neighbors as having good motivation in promoting a better life, and this, together with the 
flourishing soil of their land, enables them to develop important roles coloring the local activities not only at the level of the province but also in the eastern part of Indonesia as well [4].

The Buginese people according Thomas Stamford Raffles, originated from land is Celebes (Sulawesi), Bugis is maritime nations and trading center of being large in the archipelago, while the guy with the body of stature not too high and they will be among the intrepid, the most adventurous, got spirit is high among the nations in the east and most of all they gained a much have adventure life. Period since the conquest of the Netherlands in the 17 th century to cause some of this tribe to move around and mingled with other peoples in various an area such as Sumatra, Kalimantan, Java, as well as in Maluku, Papua, a peninsula Malaysia, Sabah and including Sarawak [5]. Traditional Phinisi ship is used by Buginese sailors to sail travel over sea and ocean, The Phinisi ship used by Buginese reach to Australia, Madagascar, and South Africa. The Phinisi ship use to trading, because this ship can load 20 to 100 tons, the greatest compared to other traditional ship design in Indonesia. This ship is capable sail in big sea and oceans. Phinisi ship having two a tall pole each of which equipped large as a mainsail and coupled with a small display on the shoots of pillars, then a boat equipped with machines in the middle part of and two a rudder that located at the back. Buginese people have good sense for making a Phinisi ship until now, where they artist build ship without blueprint design, all forms design can described in their memorize. Build the ship it usually has skill fullness who have inherited hereditary their great-grandparents. Although made traditionally of boards or beam, but toughness this ship been proven and received recognition in national and international. They capable build a ship in various size from small ship even greatest [2].

Economic liberalization and technological innovations are changing the dimensions of markets. Both phenomena drive increasing economic integration in the world, making national borders irrelevant to global commerce [6]. The Problem is not all result culture from tribe in Indonesia which able to reach the global market. From this problem researcher write this paper and want to show how the potential value of a Phinisi ship design can sustain even reach the global market. Researcher hope cultural heritage of Indonesia be improved so that many cultural result from Indonesia reach global market.

\section{LITERATURE REVIEW}

The process develop Phinisi Ship, they have traditional ritual count good day for seeking iron wood to use in build ship. Usually good day count in five or seven in month. Number 5 (naparilimai dalle'na) containing the meaning of the provision already in. Number 7 have the meaning (natujuangi dalle'na) meaning the always get provision. After the ritual, Head of the ship maker lead for searching iron wood. Next process is laying wood ship base for build vesse, by putting the wood base facing north eastern. Where the beam base in front part called as man, and while wood beam in the back of context are considered to be called woman. After that process cutting need spell to cut, the part of this process is with a saw. The process of cutting that is done with a saw, this work must doing it at once without stopping before beams wood is cut off. This cause when cutting wood process need to be done by strong person. Next the build of this ship body, ivory, shipyard, deck, chambered a ship, the construction of the screen and sails and finishing, in which every single the phases of the process always preceded by certain ritual [8]. 


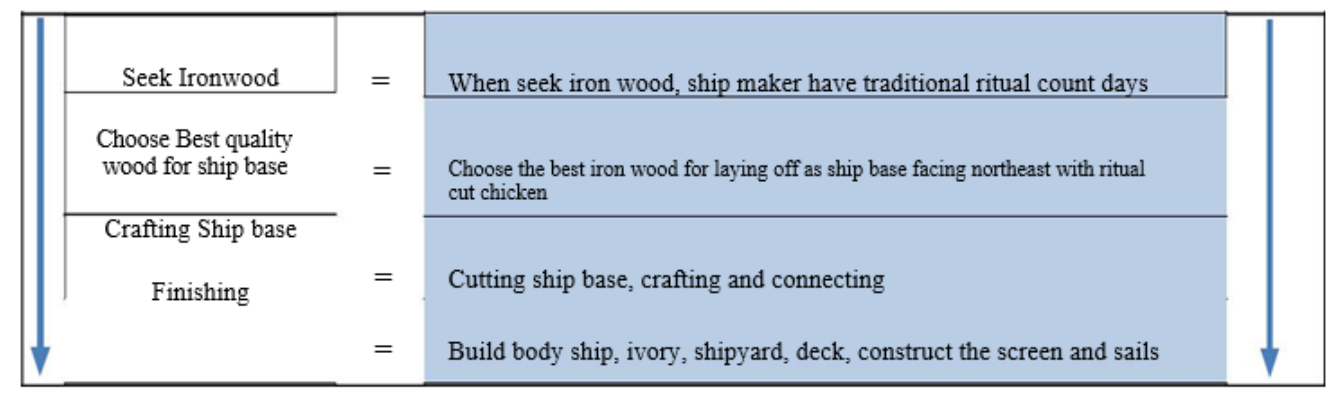

Figure 1. Design method Phinisi boat \& overview

From time to time, Phinisi has been made in many size with a traditional way. In the past, Phinisi made is tending smaller than now. Phinisi design have a development in time can reach length 30 - 40 meters, and even occasionally there are 50 meters which is the size of way to 165 feet on deck or greater. Then through the data that has been obtained, researchers will see the division of the blue print of a ship Phinisi in exterior and interior part of a Phinisi ship in traditional.

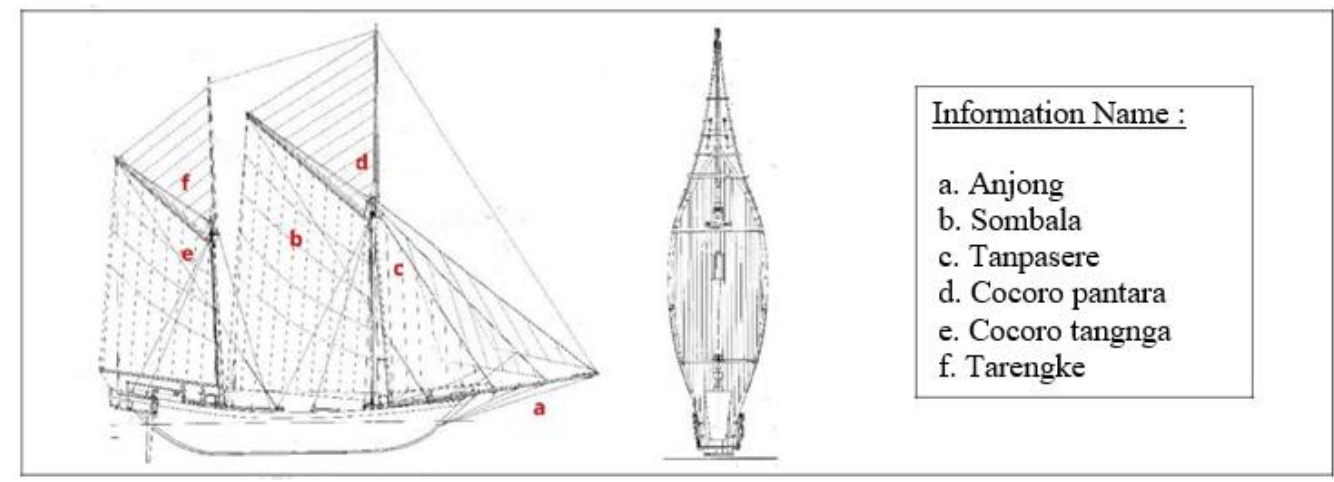

Figure 2. Blue Print Phinisi Boat Traditional with information.

As has already been discussed in the background, Phinisi ship is one of design originated by buginese people in Indonesia since 14th, until now the ship design had survives as sustainability design. What is it sustainability design, the design is development that meets the needs of the present without compromising the ability of future generations to meet their own needs [11]. Design for sustainability need approaches to innovation, that's why every product to sustain need redesign focus on 3 element: Environment, Equity / Society, and Economy. When researcher talk about product design, then it need to look in factor that supports a product can achieve success in market. Three aspects that need attention in one product can reach the market; First A market segment is Represents an effort to identify and categorize groups of customers and countries according to common characteristics. Second Targeting is the process of evaluating segments and focusing marketing efforts on a country, region, or group of people that has significant potential to respond Focus on the segments that can be reached most effectively, efficiently, and profitably. Third Positioning is required to differentiate the product or brand in the minds of the target market [3]. 


\section{RESEARCH METHOD}

This research used a qualitative descriptive approach by conducting a case study on phinisi boat design. Methods of data collection are done by conducting a literature review book, video, and images from online resources. After researcher get understanding from Phinisi boat traditional design and background, Researcher analyse data design with discussion STP (Segmentation, targeting, and Positioning).

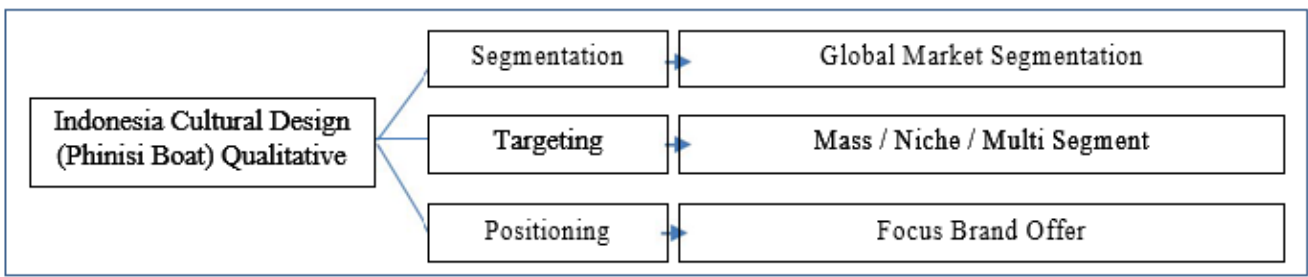

Figure 3. Research Method with STP

\section{RESULT AND FINDINGS}

In this research, will discuss the results of Buginese Phinisi ship as one of sustainability design in Indonesia that having good analyse in STP Market (Segmentation, Targeting, and Position). It with the result achieve success in global market. In the interest of achieve a design sustainability Indonesia cultural, it needs to be conducted an approach with the invention in design. Traditional Phinisi ship to be new or could be called with the approach sustainability in innovation [2].

\subsection{Segmentation}

Segmentation can be successful if: Measurable (Size, purchasing power, and profile of segment), Accessible (Can be reached and served), Substantial (Large and profitable enough to serve), Differentiable (Respond differently), Actionable (Effective programs can be developed). If we study about Phinisi Ship design product, we can see about segmentation product in demographic segmentation about lifestyle segmentation in global society. People now it has one lifestyle, who is loved about luxury stuff [1]. The goods these day have been upgraded into a luxury item including Phinisi ship made into the lifestyle segmentation of luxury goods in this millenial era.

\subsection{Targeting}

Targeting in general can be divided into three namely Mass Product, Niche Product, and Multi Segment product. When the researcher discusses sailing ship with magnificent like a Phinisi ship. Researcher also can imagines a segmentation of the intended market. In this stage that possible targeting market is Niche Marketing A single marketing mix for one segment of the market. The Phinisi ship is perfect for luxury cruises that sell about luxury and comfort in sailing. Researcher also look for example case with several companies.

\subsection{Positioning}

Positioning, the way the product is defined by consumers on important attributes - the place an offering occupies in consumers' minds on important attributes relative to competing products. Example : Volvo "safety", Mercedes "luxury”, BMW "Performance”, Dunkin Donuts "coffee 
for the average Joe", Starbucks "an experience for the gourmet coffee drinker", Coca Cola "Coke side of life". So if we want to give one position market in the brand value Pinisi ship accordance with the discussion above we can entice one position brand for it is "Adventure with Luxury".

\subsection{Example Case}

In this section researcher will show example case design of Phinisi ship be adapted to STP Marketing that has been discussed, the example case using the STP marketing from ZEN (Global Adventure Group Ltd). They company at Indonesia Yacht Charter, the group of adventure [6]. The following researcher will also show contemporary designs used by ZEN to achieve the needs of the global market.

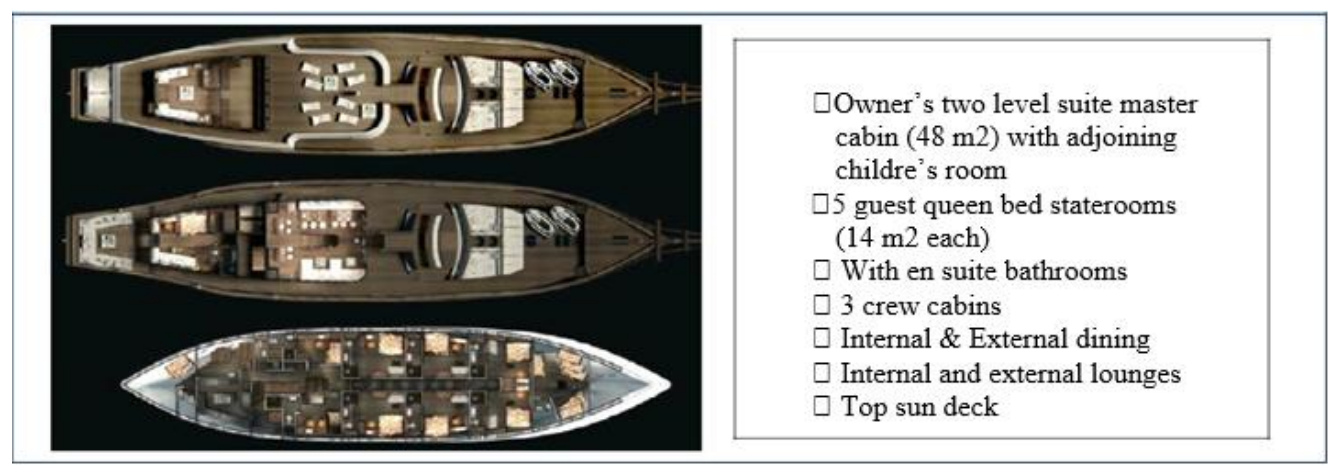

Figure 4. Cabin \& On board spaces ZEN catalogue

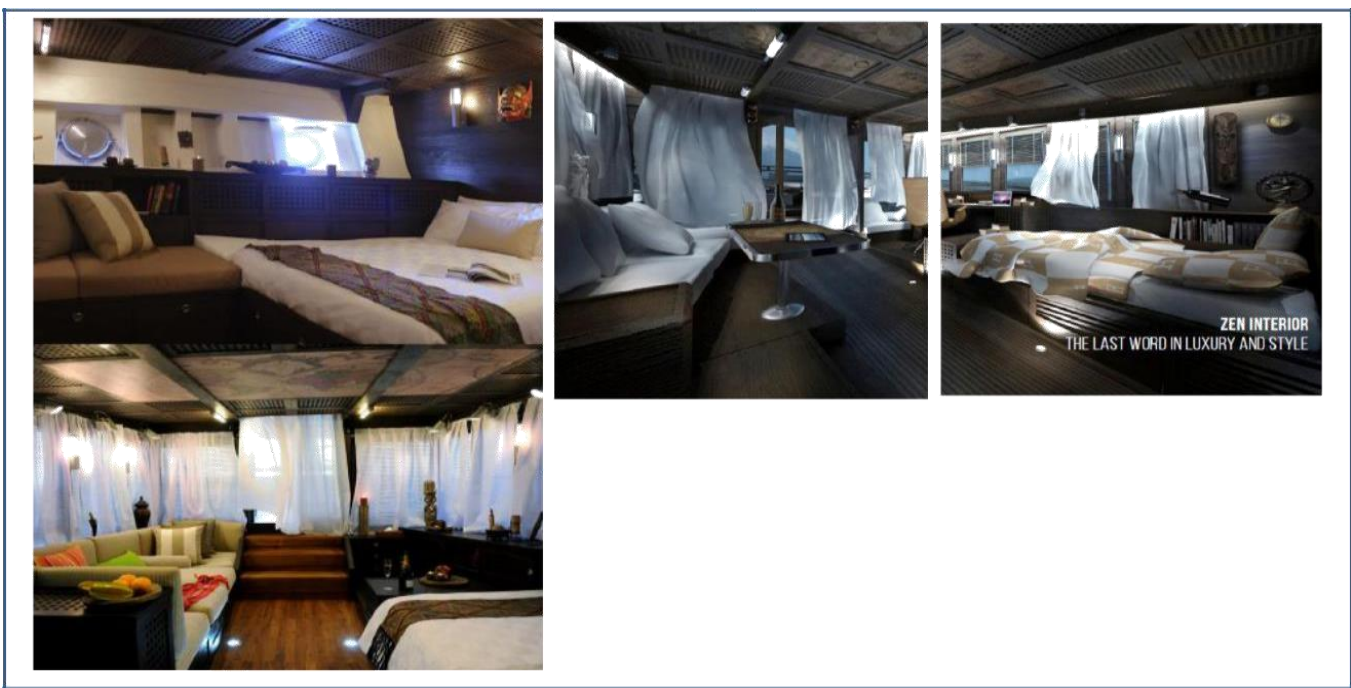

Figure 5. Interior Design Phinisi Ship Luxury(ZEN) 

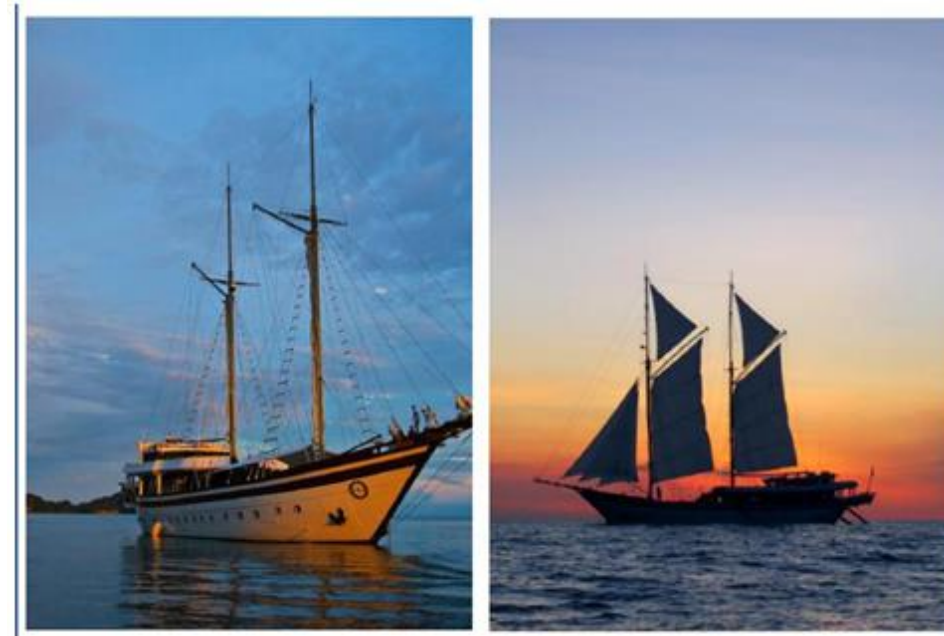

Built in Bira, Sulawesi,

2012 - Buginese

People

Number of guests: 14

pax

Number of crew: 17

pax

LOA: $53 \mathrm{~m}$

LOD: $45 \mathrm{~m}$

Beam: $9.5 \mathrm{~m}$

Draught: $3.8 \mathrm{~m}$

Top speed: 11 knots

Cruising speed: $8-9$

knots

Communication:

satellite phone,

wi-fi on board

Sail area: $650 \mathrm{~m} 2$

Figure 6. Phinisi Ship Exterior - Vessel Specification (ZEN Catalogue)

\subsection{Chart Method of Sustainability Design Culture}

Through this study, researcher tries to make a chart of the result from Phinisi ship case study sustainable design, which can be recommended as a pattern in method to be applied for cultural results.

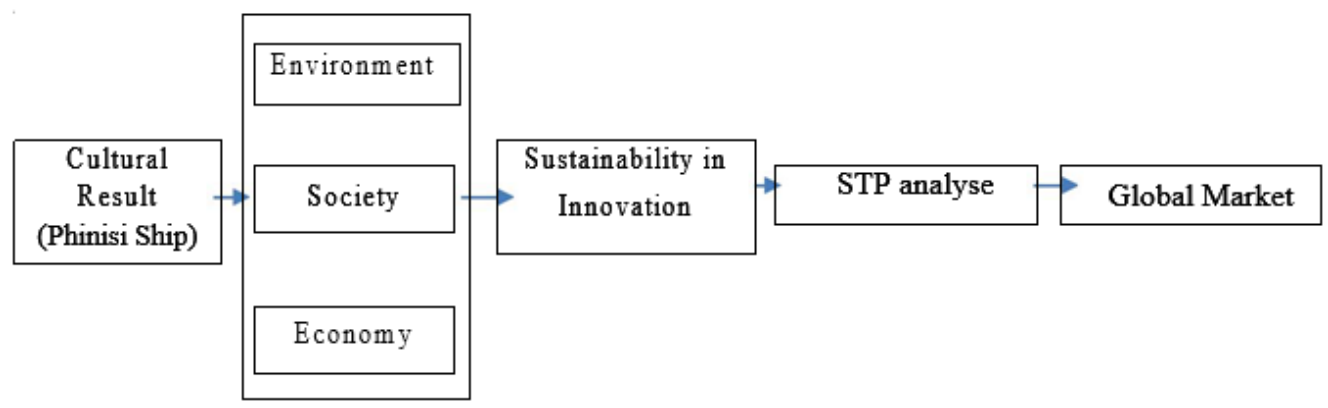

Figure 7. Chart Method of Sustainability Design Culture

\section{CONCLUSION}

Contemporary Design is The Design of today, produced with global influenced, cultural diverse, and technologically advancing world [13]. In this research Indonesian cultural design can sustain with contemporary design when traditional design always updated with 3 elements that support the development of its design; Environment, Society, and Economy. The existence of a strong cultural environment for Buginese people who keeps preserve Phinisi ship design and also the cost factor supporting developed them as to make a sustainable design can follow the global market today. The Phinisi ship also has the right STP analysis that can achieve sales in the ever-expanding global market for the global community to this day. 


\section{REFERENCES}

[1] D'Arpizio C, Levato F, Zito D, Kamel M A, and Montgolfier J D 2017 Luxury Goods Worldwide Market Study, Fall-Winter 2016 Bain \& Company

[2] Clark G, Kosoris J, Hong L N and Crul M 2009 Design for Sustainability: Current Trends in Sustainable Product Design and Development Journal Sustainability 1 409-24

[3] Camilleri M 2018 Market Segmentation, Targeting and Positioning Travel Marketing, Tourism Economics and the Airline Product (Cham, Switzerland: Springer) pp 69-83

[4] Forshee J 2006 Culture and Customs of Indonesia (Westport, London: Greenwood Press)

[5] Fox E M 2001 Global Markets, National Law, and the Regulation of Business: A View From the Top St. John's Law Review 75 383-400

[6] Global Adventure Group Ltd Luxury Phinisi Schooner Luxury Phinisi Schooner

[7] Harun M H, Katutu B and Yahya S Rachmawati 2013 Diaspora Bugis Di Sumatra Thesis (Tanjong Malim: Universiti Pendidikan Sultan Idris)

[8] Lantara D 2014 Kapal layar phinisi, PERT, proses produksi, waktu pesimistik, optimistik Jurnal Energi dan Manufaktur 795-102

[9] Lisbijanto H 2013 Kapal Pinisi (Yogyakarta, Indonesia: Graha Ilmu)

[10] Nontji A 2017 Ekspedisi Perahu Layar Tradisional Phinisi Nusantara, JakartaVancouver 1986 Oseanografi

[11] Ruggles R, Phansey A and Linder B Guide to Sustainable Design (Solidworks)

[12] Said N 2004 Religion and Cultural Identity Among the Bugis Inter-Religio 45

[13] Smith T and Mathur S 2014 Contemporary Art: World Currents in Transition Beyond Globalization Contemporaneity: Historical Presence in Visual Culture 3 163-73

[14] Yulianto A 2017 Pinisi Masuk dalam Warisan Budaya Tak benda UNESCO

\section{Acknowledgments}

This research was supported by the Animation Program, Visual Communication Design Department, School of Design, Bina Nusantara University, Jakarta - Indonesia 11480. 